\title{
RIVERS AND PORTS IN TRANSPORT HISTORY OF CAMEROON, 1916-1961
}

\author{
Walter Gam Nkwi* \\ http://dx.doi.org/10.4314/og.v13i 1.11
}

\begin{abstract}
In direct contrast to Europe, Asia and North America, Africa has very few navigable rivers. This paper focuses on the preponderant role played by water transport in the form of rivers and ports during the colonial period. Although not blessed with much navigable rivers and natural deep ports, the Colonial administration as well as the population of Cameroon depended so much on rivers and ports for their physical mobility, transportation of bulky goods, mails migration and above all European consumer goods which came in from Europe and were head loaded into the hinterlands. Therefore rivers and ports played economic, social and political roles. Despite these important roles, the place of rivers and ports has been relegated to footnotes in historical narratives of Cameroon. This paper therefore, aims at lifting rivers and ports from the footnotes of Cameroon history into the text. It confronts the importance of such a technological system to both the colonial administration and the indigenous population. What were the type of goods that were transported via rivers and ports? More crucial to the essay is the importance of the ports in the development of the cities and the migration of people into areas where ports were found. In what ways do we linked the ports and rivers to the global mobility of goods and modernity?
\end{abstract}

\section{Introduction}

In Africa and the world over, water transport had been very crucial for the movements of goods and people. The Dutch Social historian, Jan-Bart Gewald, in his study of Zambia and other Southern African countries, notes that even before colonial rule, canoes were found on Lakes Mweru, Bangweulu and Tangayika, where they were primarily used in the bulk transport of goods destined for the East African coast. On the Luapula river system, a series of societies and economies developed that was dependent on fishing and also used the river for transport. (Gewald, 2009: 26-27). Either in the North, 
Nkwi: Rivers and Ports in transport history...

Central and West Africa, rivers and ports played almost the same functions. Much has been noted about rivers in Africa like Rivers Niger, Nile, Limpopo, Zambia, just to name but a few. These rivers played the roles of transporting people from one place to another at a time when bridges were still under construction. Rivers also provided food in the form of fish to its indigenous peoples. Hopkins (1973: 43) maintains that fishing was a very important activity which took place on the waters of River Niger and Lake Chad. He further maintains that specialized communities of fishermen are known to have developed in this region with technological knowledge of carving canoes and reading the tides. Rivers have played cradle to world civilizations. For instance, the Nile, Tigris and Euphrates are well known for generating the first civilizations (Marvin and Perry, 1989).

Other rivers have been subjects of diplomacy. Following the Berlin West African conference of 1884 the Niger-Benue became international rivers (Fanso, 1989:21) Furthermore, Hassan and Rasheedy (2007: 25-27) and Webster and Boahen (1980), have done some excellent work on the Nile and Niger and how it influenced Egyptian foreign policy. Economics was directly linked to diplomacy and rivalry among European powers. The exploration of the Senegal and Niger rivers raised great hopes among traders and imperialist back in Europe. One of the diplomats attested that, "The long sought for highway into central Africa was at length found in rivers Nile and Niger. To the merchant, it offered a boundless field of enterprise, to the manufacturer, an extensive market for his goods" (Webster and Boahen, 1980: 53). The discovery of the mouth of River Niger coincided with the abolition and suppression of transAtlantic slave trade, when new commodities and new markets had to be found to replace the lost ones. The Europeans tried to fill the gap by trading along the Senegal and the Niger rivers. Between 1817 and 1840, for instance, the French tried to establish plantations along the Senegal and between 1818 and 1821 they built forts on the River Senegal at Bakel, Dagone and Richard Toll. In 1832, the British and the Americans also each sent out and expedition to travel up the Niger and set up trading stations on its banks for the purpose of collecting the various products of the country. Other expeditions by British merchants followed in 1836 and 1840 and 1841 the abolitionists led by Fowell Buxton persuaded the British government 
to send a carefully prepared expedition to establish legitimate trade and set up experimental farms in order to overthrow the slave trade. As a matter of fact the interest of the British traders before 1880 were highly concentrated mainly in along river Niger where the palm oil trade, which together with groundnuts was the only major produce of West Africa of interest to Europe at the time (Crowder, 1968; Webster and Boahen, 1973) All these efforts by the British, French and Americans ended up in fiasco partly because of the resistance from traditional rulers, middlemen and the high death rate of shipping crews.

The economic importance of rivers was further echoed by Kenneth Onwuka Dike. According to him "It was as navigable waterways that the rivers of the Niger Delta became so important in the economic history of modern Nigeria. A canoe would be taken from Badagry on the West coast of Nigeria to Rio del Rey in the east without going into the open sea" (Dike, 1956:20). Harry Johnston further maintained amongst other things that "....there are hardly any roads existing in the Delta; the most trivial distance that a native requires to go, he generally achieves in a canoe. This water system links the Delta with the markets and sources of production far inland"(Oliver, 1958: 123). These show how rivers played an important economic role in Africa. Apart from the economic role, rivers also played socio-cultural and political roles which this paper hopes to unravel.

Ports were not a new invention by the colonial regimes in Africa. As a matter of fact many fishing ports existed in many parts of the African and Cameroon coast and it was on this that the colonial administration improved on the harbours to facilitate bigger launches to anchor. During the colonial periodin West Africa almost everywhere on the coastline ports developed to take new directions. During the era of slave trade, these ports were used for the shipment of slaves to the Americas. During the so called legitimate trade these ports played the role of delivering modern merchandise from Africa to Europe and vice versa. In a period when airports were absent, ports played the role of transporting people and goods to further distant spaces. In Cameroon, I am more interested in the Victoria and Tiko ports. The renowned port of Douala has been exhaustively handled by Fomin (2010) by illustrating and showing the vicissitudes of ports in Africa 
Nkwi: Rivers and Ports in transport history...

\section{The significance, methodology and structure of the paper}

The historiography of Cameroon has occupied some space in the academia (Aka, 2002; Rubin, 1971; Welch, 1960; Fanso, 1989; Johnson, 1970; Le Vine, 1971; Mveng, 1961; Brain and Mbuagbaw, 1970; Ardener, 1956; Ardener, 1968; Ngoh, 1987 and 2004). As rich as the literature might appear there is still paucity in the direction of transport history and more particularly, the role which ports and rivers played. Fomin (2010: 171-186) has provided an incisive discourse on the vicissitudes of African ports by taking the Douala port as a case study. Rudin (1938: 103), have noted that the port of Douala “...was one of the best ports in West Africa”. He also attempted to document the navigability of Cameroon Rivers and the challenges and difficulties they have posed to the indigenous people and colonial administration. Apart from the works of Fomin and Rudin, other ports like Tiko and Victoria as well as rivers have remained a tabula rasa in the historiography of Cameroon. This is a gap which this paper sets out to fill.

At the nascent years of colonial rule, European administration faced insurmountable challenges and difficulties. One of the areas which affected their work was in the domain of transport. Contrary to the opinion that most if not all what was found in Africa during the colonial rule, the European themselves had to make do with what they found in the territory. It was in this light that water transport-be it rivers or ports became very important and had been well exploited by the pre-colonial people.

The materials for this paper were gathered from different repositories. The Buea National Archives, located in Buea capital of Southwest Region of Cameroon was relevant. Files on the operation of these ports and rivers were found although some were partially destroyed. In the Public Records Office, London which I entered from November to December 2007, there was relevant material on rivers Ordinance passed by the British in 1927.The archives of Mission 21 Basel, Switzerland, which I visited in 2008 contain historical photographs which I have included some relevant ones in this paper. After the archives, I conducted interviews with people who lived through the experience during the period within study. The photographs also became a source which was exploited to graphically illustrate situations. As we all know photographs can tell more than words. 
This paper is structured into the following parts: the first part focuses on the Tiko and Victoria ports in their colonial context under the British colonial administration. I then proceed to examine the Victoria port city which was an offshoot of the port itself. The third part focuses on the Victoria port at work. This takes up the ports as areas which attracted people because of their admiration to modernity goods which were passing through the ports. The fourth part examines the voices of the Victoria and Tiko migrants back in their areas of origins. The sixth section examines the ports and consumption and shows how those who accessed the port cities displayed their conspicuous consumption and how these port cities became areas of cultures. The seventh section takes up rivers and focusing and their economic, political and socio-cultural importance in Cameroon history. The eighth section examines the rivers, canoes and canoe boys while the last section is the conclusion.

\section{Victoria and Tiko Ports}

The port of Victoria was founded long before German colonisation by the Baptists Missionaries led by Alfred Saker. The Germans envisaged creating a commercial economy. That ambition was well executed when volcanic soils which are often fertile for agriculture led to the opening of plantations both in Victoria and coastal Cameroon. These plantations produced various agricultural products such as palm oil, rubber, bananas, pepper and cocoa (Epale, 1985; Rudin, 1938; Fanso, 1989). To get these things shipped to Europe water transport became a sine qua non and by extension a seaport. Although the Victoria and Tiko seaports were officially opened in the 1880 s they reached their heydays only in the 1920s during the British colonial administration. It was during that period that Victoria and Tiko ports became the first ports in the British Southern Cameroons and linked the territory to the global movements of goods and people.The foundation of Victoria was traced to the London Baptist Missionaries who were led by Alfred Saker. On 23 August 1858 Alfred Saker signed a treaty with King William of Bimbia who claimed to have had unlimited powers over the land arranging for its purchase at the cost of $£ 1,800$. After the abolition of slave trade in the British Empire in the early 1830s some 
emancipated slaves from Jamaica pressed for an evangelical mission to return to the African homeland. In England the religious motive was complemented by a search for scientific and economic goals geared towards the opening up of more lands in Africa. In 1841, the Niger Expedition was launched with the primary goal of opening up modern day Nigeria to British traders, missionaries and scientists. The Committee of the London Baptist Missionary Society (LBMS) took advantage of the abolition of slavery and the slave trade in the British Empire as well as the Niger Expedition and decided that an effort be made to give the light of life to Dark continent and also to atone for the crimes that the English greed had for centuries committed by proclaiming in Africa itself the glad tidings of divine liberty from high (Fanso, 1989)

Consequently, the missionaries left England on 13 October 1840 and reached Fernando Po (Present day Equatorial Guinea) and reached their destination on January 1841. While in Fernando Po they were given an introductory letter by the former Governor of Fernando Po, Lt. Colonel Nicolls. In 1845, the Spanish Consul, General Don Carlos Chacon, arrived Fernando Po with instructions to send the Baptist Missionaries away unless they agreed to stay in a private capacity only. Although they refused they were allowed to stay unmolested until after 1856 when the Spanish Catholics in Fernando Po made things quite difficult for them. In May 1858 the Spanish Jesuits arrived the island and proclaimed Catholicism the main religion. Thence, Alfred Saker decided to move with his followers in Fernando Po to the mainland opposite the island, this was Bimbia but after he acquired it, he named it Victoria in honour of Queen Victoria of England (Underhill, 1958).

Saker's expulsion from Fernando Po had different but contrasted motives. He was expelled because of religious and to a lesser extend economic motives. His decision to find Victoria was also due to religious and economic motives. Writing about this view, Saker's biographer, Edward Bean Underhill said inter alia:

I (Alfred Saker) need a home for our people where a trade may be created and to which commerce may be drawn. I searched for a landing only....Here if Her Majesty's Government sanction and sustained our efforts, can be put, coal stores, provision stores, building yards and every other 
essential for commerce. Here too a highway may be made into the interior and the native produce be shipped in smooth water for Europe. It will be essentially a religious enlightened colony.... (Underhill, 1958:56)

If well scrutinized, it will be deduce from Saker's words that there were already ingredients of a sea port as early as 1858 . Secondly, it also shows that the foundation of Victoria was due to religious as well as economic motives.

The beginnings of Victoria port could be traced to the 1880 s when the Germans annexed Cameroon. The Germans envisaged creating a commercial economy. That ambition was well executed when volcanic soils which are often fertile for agriculture led to the opening of plantations both in Victoria and coastal Cameroon. These plantations cultivated various agricultural products such as palm oil, rubber, bananas, pepper and cocoa (Epale, 1985). To get these things shipped to Europe water transport became a sine qua non and by extension a seaport. Although the Victoria seaport was officially opened in the 1880s it reached its heydays only in the 1920s during the British colonial administration. It was during that period that Victoria became the first city in the British Southern Cameroons.

Victoria during the British colonial administration was the capital of Victoria Division. It had a land surface of 1,166 sq.miles ${ }^{1}$. Victoria became the economic nerve center of many commercial activities. It all began with the opening of commercial firms as well as trading companies. Table 1 show the number of companies and their nationalities as well as some business magnets that were found in Victoria.

\section{Table I: Trading Companies and Merchants in Victoria}

\begin{tabular}{|l|l|l|l|}
\hline $\begin{array}{l}\text { Name of } \\
\text { Company }\end{array}$ & Nationality & $\begin{array}{l}\text { Nature of } \\
\text { Business }\end{array}$ & Remarks \\
\hline $\begin{array}{l}\text { Woodin and } \\
\text { Co. Limited }\end{array}$ & British & Export and Import & $\begin{array}{l}1916 \\
\text { operating a } \\
\text { branch in } \\
\text { Victoria }\end{array}$ \\
\hline
\end{tabular}

${ }^{1}$ File Ba (1938) Cameroons Province : Notes for the League of Natiions Report 1938.(National Archives Buea (NAB), 
Nkwi: Rivers and Ports in transport history...

\begin{tabular}{|c|c|c|c|}
\hline $\begin{array}{l}\text { John Holt and } \\
\text { Co. }\end{array}$ & British & $\begin{array}{l}\text { Export, Import and } \\
\text { Retail }\end{array}$ & $\begin{array}{l}\text { Established } \\
\text { in Victoria in } \\
1933\end{array}$ \\
\hline $\begin{array}{l}\text { Compagnie } \\
\text { Forestiere } \\
\text { Sangha } \\
\text { Oubangui }\end{array}$ & French & Forestry & $\begin{array}{l}\text { Established } \\
\text { in } 47\end{array}$ \\
\hline $\begin{array}{l}\text { Jacob } \\
\text { Adebona }\end{array}$ & Nigerian & Petty Trader & $\begin{array}{l}\text { Had factories } \\
\text { in Victoria as } \\
\text { early as } 1916\end{array}$ \\
\hline $\begin{array}{l}\text { J. Lawani } \\
\text { Marsha }\end{array}$ & Nigerian & Retail Petty trader & $\begin{array}{l}\text { Established } \\
\text { in } 1924\end{array}$ \\
\hline Z.P. Thorpe & $\begin{array}{l}\text { Sierra } \\
\text { Leonean }\end{array}$ & Retail Petty trader & $\begin{array}{l}\text { Established } \\
1924\end{array}$ \\
\hline $\begin{array}{l}\text { A.G. } \\
\text { Thompson }\end{array}$ & Togolese & Retail & $\begin{array}{l}\text { Established } \\
1923\end{array}$ \\
\hline Body Lawson & Togolese & $\begin{array}{l}\text { Trader- } \\
\text { Importer/Exporter }\end{array}$ & $\begin{array}{l}\text { Established } \\
1923\end{array}$ \\
\hline S.D. Johnson & Togolese & Importer/Exporter & $\begin{array}{l}\text { Established } \\
1922\end{array}$ \\
\hline Sillas Attipo & Liberian & Trader & $\begin{array}{l}\text { Established } \\
1923\end{array}$ \\
\hline S. Hays & $\begin{array}{l}\text { Sierra- } \\
\text { Leonean }\end{array}$ & Trade & $\begin{array}{l}\text { Established } \\
1922\end{array}$ \\
\hline $\begin{array}{l}\text { Charles } \\
\text { Abbey }\end{array}$ & Monrovian & Trader & $\begin{array}{l}\text { Established } \\
1922\end{array}$ \\
\hline $\begin{array}{l}\text { Mpondo } \\
\text { Elame alias } \\
\text { Freeborn }\end{array}$ & $\begin{array}{l}\text { Douala- } \\
\text { Import and } \\
\text { Export }\end{array}$ & Wholesale trader & $\begin{array}{l}\text { Established } \\
1922\end{array}$ \\
\hline Grenoulleau & French & Retail & 1919 \\
\hline De Bandera & Greek & Retail & 1921 \\
\hline Hausa Co. & British & $\begin{array}{l}\text { Dealer of goods of } \\
\text { German origin }\end{array}$ & 1923 \\
\hline
\end{tabular}

SOURCE: Simon Joseph Epale, Plantations and Development in Western Cameroon, 1885-1975: A study in Agrarian Capitalism (Los Angeles: Ventage Press, 1985) 
From the table above, the interconnectedness with the outside world of Victoria cannot be left in doubt. Victoria was becoming a veritable hub where much commercial activities were taking place. Traders came from West African coast, Greece and France. Most of the companies were British. A closer look at the table also reminds us of Victoria as a portal of globalization. Middell and Naumann (2010:149-170) has observed that such windows through which globalisation is understood could be those places which have acted as centers of world trade or global communication, and have served as entering points for cultural transfer and where institutions and practices for dealing with global connectedness have been developed. The strength of the above scholars suggests that trade was at the center of globalisation. Apart from what is obtained in the table, in 1909 Victoria alone had 18 firms in active operation with 99 European employees and 4, 184 Cameroonian employees.

From Victoria some of the business firms radiated their activities to the hinterlands such as John Holt and United African Company. John Holt was the earliest company to be established in Victoria. This company specialised in buying palm products like kernels and palm oil. These products were very essential for the survival of factories back in Europe. With some of these products margarine was produced. In the 1930s, John Holt already had branches in Kumba and Bamenda all inland cities. The United Africa Company (UAC) was a British company which principally traded in West Africa during the 20th century (Baker, 1996; Fage et.al., 1995). Both companies, which specialised in the exploitation and trading of palm kernels and palm oil which were exported. Although by 1928 ,there was keen competition between these companies in the 1930s UAC established the oil extracting and kernel cracking machine around Mamfe on the headwaters of River Manyu. The entire palm products passed through Victoria port to Europe ${ }^{2}$.

${ }^{2}$ File, No.156/1930 Ce (1930) 1, Mamfe Division Annual Report 1930; File No. 177/1931, Ce (1931)1 Mamfe Division Annual Report; File No. (1934) 1, Mamfe Divisional Report, 1934; File No. 1781 Ce (1935) 1, Mamfe Division Annual Report (NAB) 
Nkwi: Rivers and Ports in transport history...

\section{The Victoria Port at Work}

For a better appreciation of the Victoria as a port city it is imperative to understand that it developed during the political transformation of the territory. As a matter of fact, during the mandate and trusteeship period, the port experienced its busiest period. The companies and firms in Table 2 imported various items which included bags and sacks, cement, cigars and cigarettes, cotton piece goods, fish, Kerosene in imperial gallons, motor spirits, rice, bicycles, radios, tilly lamps ${ }^{3}$ just to name but a few. Table II Shows the products which entered through Victoria port between 1933 and 1937.

Table II: Principal articles of import during the period 19331937

\begin{tabular}{|l|l|l|l|l|l|}
\hline YEARS & $\mathbf{1 9 3 3}$ & $\mathbf{1 9 3 4}$ & $\mathbf{1 9 3 5}$ & $\mathbf{1 9 3 6}$ & $\mathbf{1 9 3 7}$ \\
\hline $\begin{array}{l}\text { Bags and } \\
\text { sacks in } \\
\text { dozens }\end{array}$ & 5,851 & 6.090 & 7,886 & 7656 & 107,975 \\
\hline $\begin{array}{l}\text { Cement in } \\
\text { tons }\end{array}$ & 326 & 519 & 801 & 1,474 & 2,373 \\
\hline $\begin{array}{l}\text { Cigars } \\
\text { and } \\
\text { cigarettes } \\
\text { in Hds }\end{array}$ & 14,489 & 11,934 & 12,465 & 13,0009 & 11,835 \\
\hline $\begin{array}{l}\text { Cotton } \\
\text { Piece } \\
\text { Goods sq. } \\
\text { qty }\end{array}$ & 658,355 & 610,722 & $1,134,447$ & $1,155,423$ & $1,676,915$ \\
\hline $\begin{array}{l}\text { Fish Lb } \\
\text { Kerosene } \\
\text { imp.gallons }\end{array}$ & 43,860 & 34,572 & 40,998 & 73,560 & 54,697 \\
\hline
\end{tabular}

${ }^{3}$ Report by His Majesty Government in the United Kingdom of Great Britain and Northern Ireland to the Council of the League of Nations on the Administration of Cameroons under British Mandate for the year 1937 (NAB) 
Ogirisi: a new journal of African studies vol. 132017

\begin{tabular}{|l|l|l|l|l|l|}
\hline $\begin{array}{l}\text { Motor } \\
\text { Spirit in } \\
\text { Imp. } \\
\text { Gallons }\end{array}$ & 61,761 & 47,438 & 69,425 & 78,356 & 64,837 \\
\hline $\begin{array}{l}\text { Rice in } \\
\text { cwt }\end{array}$ & 12,938 & 16,530 & 19,938 & 36,601 & 36,425 \\
\hline Salt & 8,939 & 8,856 & 10,828 & 11,085 & 12,371 \\
\hline $\begin{array}{l}\text { Tobacco } \\
\text { Lb }\end{array}$ & 21,015 & 11,040 & 11,387 & 19,425 & 10,923 \\
\hline
\end{tabular}

These imports were matched with exports in the same period. And these articles passed through Victoria port. Table 3 shows the principal articles of export.

Table II: principal articles of export

\begin{tabular}{|l|l|l|l|l|l|}
\hline YEARS & $\begin{array}{l}\mathbf{1 9 3 3} \\
\text { TONS }\end{array}$ & $\begin{array}{l}\mathbf{1 9 3 4} \\
\text { TONS }\end{array}$ & $\begin{array}{l}\mathbf{1 9 3 5} \\
\text { TONS }\end{array}$ & $\begin{array}{l}\mathbf{1 9 3 6} \\
\text { TONS }\end{array}$ & $\begin{array}{l}\mathbf{1 9 3 7} \\
\text { TONS }\end{array}$ \\
\hline Bananas (dried) & 533 & 537 & 740 & 455 & 630 \\
\hline Bananas (fresh) & 16,789 & 22,781 & 37,752 & 49,605 & 55,737 \\
\hline Cocoa & 3,608 & 4,561 & 4,073 & 4774 & 4,796 \\
\hline Kola nuts & $/$ & $/$ & $/$ & $/$ & .43 \\
\hline Palm Kernels & 1,617 & 1,283 & 1,418 & 1,506 & 1,803 \\
\hline Palm oil & 1,837 & 1,477 & 1,418 & 1,648 & 1,583 \\
\hline Rubber & 164 & 657 & 1,731 & 582 & 725 \\
\hline $\begin{array}{l}\text { Wood and } \\
\text { Timber } \\
\text { unmanufactured }\end{array}$ & 6,560 & 5,184 & 3,055 & 5,142 & 5,068 \\
\hline
\end{tabular}

SOURCE: Report by His Majesty Government in the United Kingdom of Great Britain and Northern Ireland to the Council of the League of Nations on the Administration of Cameroons under British Mandate for the year 1937 (NAB).

Tables 2 and 3 shows how transnational entanglements and global networks have not been limited to particular hubs but rather have involved in the world long before the renewed globalisation was defined (Middell and Nauman, 2010). The table shows the economic and social role which the port played in colonial Cameroon, It was not all about goods moving. Goods which symbolized globalisation and modernity gradually found themselves 
Nkwi: Rivers and Ports in transport history...

through ports and harbours before being carried by individual people into their rooms and beyond. These goods were not exported to one country neither was the port of Victoria handling sea vessels from one country. Thus within this period 52 countries docked their ships at the Victoria port with goods of various kinds. Table 4 shows these countries with the value of their imports in pounds

Table III: Value of Imports through Victoria port (1932-1935)

\begin{tabular}{|c|c|c|c|c|c|}
\hline $\begin{array}{l}\text { Country of } \\
\text { Origin }\end{array}$ & $\begin{array}{l}\text { Consignme } \\
\text { nt in } £ \\
1932\end{array}$ & $\begin{array}{l}\text { Consignme } \\
\text { nt in } £ \\
1933\end{array}$ & 1934 & 1935 & $\begin{array}{l}\% \\
\text { of } \\
\text { total } \\
\text { trad } \\
\mathrm{e}\end{array}$ \\
\hline $\begin{array}{l}\text { United } \\
\text { Kingdom }\end{array}$ & 26,245 & 22,879 & 18,713 & 26,343 & $27 \%$ \\
\hline Germany & 20,400 & 22,407 & 20,954 & 36,345 & $38 \%$ \\
\hline France & 152 & 165 & 262 & 771 & $.8 \%$ \\
\hline U.S.A & 6,037 & 4,492 & 3,657 & 4,075 & $4 \%$ \\
\hline Holland & 2,863 & 3,183 & 1,758 & 3,394 & $4 \%$ \\
\hline Japan & 811 & 798 & 4,145 & 7,239 & $8 \%$ \\
\hline Italy & 153 & 168 & 224 & 259 & $.3 \%$ \\
\hline Norway & 593 & 1,849 & 2,145 & 2,654 & $3 \%$ \\
\hline Sweden & 12 & 96 & 292 & 199 & $.2 \%$ \\
\hline Spain & 10 & 23 & 165 & 154 & $.1 \%$ \\
\hline Denmark & 70 & 121 & 493 & 465 & $.5 \%$ \\
\hline Belgium & 219 & 430 & 515 & 1,412 & $1 \%$ \\
\hline Russia & 4 & 3 & 362 & 213 & $.2 \%$ \\
\hline Portugal & 61 & 886 & 84 & 195 & $.2 \%$ \\
\hline Switzerland & 5 & 20 & 77 & 107 & $.1 \%$ \\
\hline Brazil & 1 & 2 & 127 & 161 & $.2 \%$ \\
\hline Austria & I & 162 & 23 & 52 & $\begin{array}{l}.05 \\
\%\end{array}$ \\
\hline Canada & 7 & 36 & 198 & 200 & $.2 \%$ \\
\hline India & 595 & 436 & 3,262 & 4,744 & $5 \%$ \\
\hline Gold Coast & 39 & 106 & 104 & 110 & $.1 \%$ \\
\hline $\begin{array}{l}\text { Spanish } \\
\text { Possesions }\end{array}$ & 1,819 & 1,365 & 1,038 & 1,597 & $2 \%$ \\
\hline French & 4.894 & 4,457 & 8,890 & 4,044 & $4 \%$ \\
\hline
\end{tabular}


Ogirisi: a new journal of African studies vol. 132017

\begin{tabular}{|l|l|l|l|l|l|}
\hline Possessions & & & & & \\
\hline South Africa & 12 & $/$ & $/$ & $/$ & $/$ \\
\hline $\begin{array}{l}\text { Czechoslavak } \\
\text { ia }\end{array}$ & I & I & 431 & 639 & $.7 \%$ \\
\hline $\begin{array}{l}\text { Portuguese } \\
\text { Possessions }\end{array}$ & $/$ & $/$ & 37 & $/$ & $/$ \\
\hline $\begin{array}{l}\text { Belgian } \\
\text { Congo }\end{array}$ & $/$ & 2 & $/$ & $/$ & $/$ \\
\hline Sierra Leone & 4 & $/$ & 1 & $/$ & $/$ \\
\hline China & 8 & $/$ & 12 & 63 & .07 \\
\hline Argentina & $/$ & $/$ & 80 & 201 & $.2 \%$ \\
\hline Australia & $/$ & $/$ & 11 & 68 & $\begin{array}{l}.07 \\
\%\end{array}$ \\
\hline California & $/$ & $/$ & 5 & 28 & $\begin{array}{l}.03 \\
\%\end{array}$ \\
\hline Ceylon & $/$ & $/$ & 32 & 48 & $\begin{array}{l}.05 \\
\%\end{array}$ \\
\hline Chile & $/$ & $/$ & 12 & $/$ & $/$ \\
\hline Delmatia & $/$ & $/$ & 3 & 8 & $/$ \\
\hline East Indies & $/$ & $/$ & 67 & 6 & $/$ \\
\hline Egypt & $/$ & $/$ & 28 & 39 & .04 \\
\hline Esthonia & $/$ & $/$ & 129 & 218 & $.2 \%$ \\
\hline Greece & $/$ & $/$ & 15 & 26 & $\begin{array}{l}.03 \\
\%\end{array}$ \\
\hline Hong Kong & $/$ & $/$ & 2 & 12 & $/$ \\
\hline Iraq & $/$ & $/$ & 1 & $/$ & $/$ \\
\hline Kamschatka & $/$ & $/$ & 7 & 9 & $/$ \\
\hline Kenya & $/$ & $/$ & 1 & 1 & $/$ \\
\hline New Zealand & $/$ & $/$ & 13 & 4 & $/$ \\
\hline Poland & $/$ & $/$ & 28 & 58 & $\begin{array}{l}.05 \\
\%\end{array}$ \\
\hline Uruguay & $/$ & $/$ & 31 & 26 & $\begin{array}{l}.03 \\
\%\end{array}$ \\
\hline $\begin{array}{l}\text { British West } \\
\text { Indies }\end{array}$ & $/$ & $/$ & 23 & 52 & $\begin{array}{l}.05 \\
\%\end{array}$ \\
\hline Zanzibar & $/$ & $/$ & 1 & $/$ & $/$ \\
\hline
\end{tabular}


Nkwi: Rivers and Ports in transport history...

\begin{tabular}{|l|l|l|l|l|l|}
\hline $\begin{array}{l}\text { Straits } \\
\text { Settlement }\end{array}$ & / & / & $/$ & 3 & $/$ \\
\hline Jamaica & / & $/$ & $/$ & 3 & $/$ \\
\hline Tangayika & $/$ & $/$ & $/$ & 1 & $/$ \\
\hline Roumania & $/$ & $/$ & $/$ & 8 & $/$ \\
\hline Turkey & $/$ & $/$ & $/$ & 1 & $/$ \\
\hline TOTAL & $£ 65,013$ & $£ 64,086$ & $\begin{array}{l}£ 68,46 \\
0\end{array}$ & $\begin{array}{l}£ 96,21 \\
2\end{array}$ & \\
\hline
\end{tabular}

SOURCE: Compiled from League of Nations Reports for the years, 1932, 1933, 1934 and 1935 (NAB)

Table 4 shows that 52 ships from various countries of the world docked at the Victoria port between 1932 and 1935.The United Kingdom and Germany topped the chart of trading activities. Some of the countries fizzled out with less than one percent. However, a closer look at the table could be very tricky Out of the 52 countries one wonders why California should be a country and some countries like the French and Portuguese possessions actually mean in the colonial lexicon. Countries like Jamaica, Roumania, Turkey, Zanzibar in the years 1932, 33 and 34 were completely absent and even when they came in their volume of trade was negligible. The only plausible reason to this performance might lie in the fact that Victoria was a literage port which meant that shipment and discharge was expensive. ${ }^{4}$

The countries whose vessels docked in Victoria show that although remotely global, it was a nodal junction in the global world. Victoria had become truly a funnel which globality could be consumed. According to Urry (2000), the emergence of global networks transforms the very nature of social. It can no longer be seen as bounded within national societies. He further maintains that people across the world stage are global consumers of other places and goods. On the other hand Geyer (2010), questions how and where globalisation makes its way into one's country. The role of the Victoria port which attracted more than 50 countries' vessels at its port partly answers this question. Through the port we start to

\footnotetext{
${ }^{4}$ File Ba (191962)1 Kenneth E. Berrill, The Economy of the Southern Cameroons: A Report Submitted to J.O. Fields, Commissioner of Southern Cameroons on 25 August 1960(NAB).
} 
understand the junctures of globalization which became conduits through which global commodities passed through. Once "modern" goods anchored in this port, different actors took further into the hinterlands and put in peoples' houses, kitchens and villages. The role of individuals in the dissemination of modernity could not be down looked.

\section{All Roads lead to Victoria: Migrants and the allure to Modernity} It will be misleading to see the port of Victoria only in economic terms or in terms of exports and imports. Migrants flooded into the port city in search for jobs and others only to admire the fascination of modernity. Administratively as the capital of Victoria Division migrants flooded into the city. Migrants came in from the hinterlands especially the Bamenda grassfields which included Meta, Bali, Bafut, Wum, Kom, Nso as well as foreigners like Togolese, Creole fishermen especially the Ejaw of Nigeria and Sierra Leoneans. Between 1953 and 1967 the people of Victoria was $33,000^{5}$

The colonial administration saw the need to construct roads which will help the migration of these people and goods to Victoria and the hinterlands. The importance of roads was never in doubt at the beginning of colonial venture. Speaking of German rule, Rudin (1938:237) makes the point unequivocally. 'Roads were an administrative, commercial, and military necessity from the beginning of the occupation of the colonial territory'. The interest of British colonial authorities in widening the roads was to overcome the disadvantages of the carrier system and reduce the cost of running the colony to its barest minimum, with the colony bearing the cost.

British colonial administrators in Cameroon spent enormous efforts justifying not only the inevitability but the desirability of 'good' roads, first, in the Cameroon Province and second in the Bamenda Province which were to link Victoria. From the

\footnotetext{
${ }^{5}$ Report by His Majesty Government in the United Kingdom of Great Britain and Northern Ireland to the Council of the League of Nations on the Administration of Cameroons under British Mandate for the year 1937 (NAB)
} 
perspective of the Cameroon Province, writing about the main trunk road linking Bamenda and Victoria ,port Secretary of State for the Colonies, Lennox-Boyd, statedinter alia:

I have the honour to inform you that my council of Ministers has recently had under review the adequacy of present plans for the improvement of the Federal Trunk Road A4 which runs from Victoria to Bamenda. This road which is the spinal cord of all land communications in the Southern part of the Cameroons Trust Territory must be given priority ... the opening of a all-season artery from Bamenda to the Eastern Region boundary and to the coastal ports of Victoria and Tiko is undoubtedly the prime necessity among all others at the present time ... .

In other words, Lennox-Boyd, was justifying road construction on economic grounds: roads were needed to evacuate raw materials from the hinterland to the coastal port and also to allow the movement of people. Every commentator in the territory stressed the importance of roads as the key to the future'?

The Bamenda Province had a population of about 400,000 people and most of those people were mobile despite the obstacles in their way such as wild forest and fast flowing rivers. If the area were linked by a wider road, it was an opportunity for those strong people to increase in numbers and go down to work in coastal plantations. With that agenda, the British colonial administration saw the connection of the Bamenda area to the littoral corridor especially Victoria as absolutely important.

Apart from Victoria there was also Tiko port. Tiko was a deep-sea port of considerable size constructed by a German plantation company. Several sea going vessels load and discharged

6 , File Rc 1956/2 Cameroons Road Programme Policy (NAB); Also see Public Records Office (PRO) CO 583/248/11 Cameroon Report on Road Communication (NAB)

7 File Qc (1960) Kenneth E. Berill to J.O. Fields, The Economy of the Southern Cameroons: A Report Submitted to J.O. Fields Commissioner of Southern Cameroons 25/August 1960 (NAB) 
at the port. The most important trading partner of this port was Germany. There was a weekly service between this port and the principal port of Douala ${ }^{8}$. In comparison with Victoria, the size of trade and the number of vessels which docked at Victoria were by far more than those which docked in Tiko. For instance, in 1936 alone vessels of British, German, Dutch and Norwegian nationalities docked at Tiko port while the same nationalities except American also docked at Victoria. What made the difference in the tonnage of goods. While Victoria registered a net tonnage of 367, 142 Tiko registered $156,676^{9}$.In terms of wines and whisky, the quantities differed significantly as the table IV will illustrate. Meanhile Picture one shows a ship which has docked at Tiko port.

Picture 1: The Tiko port

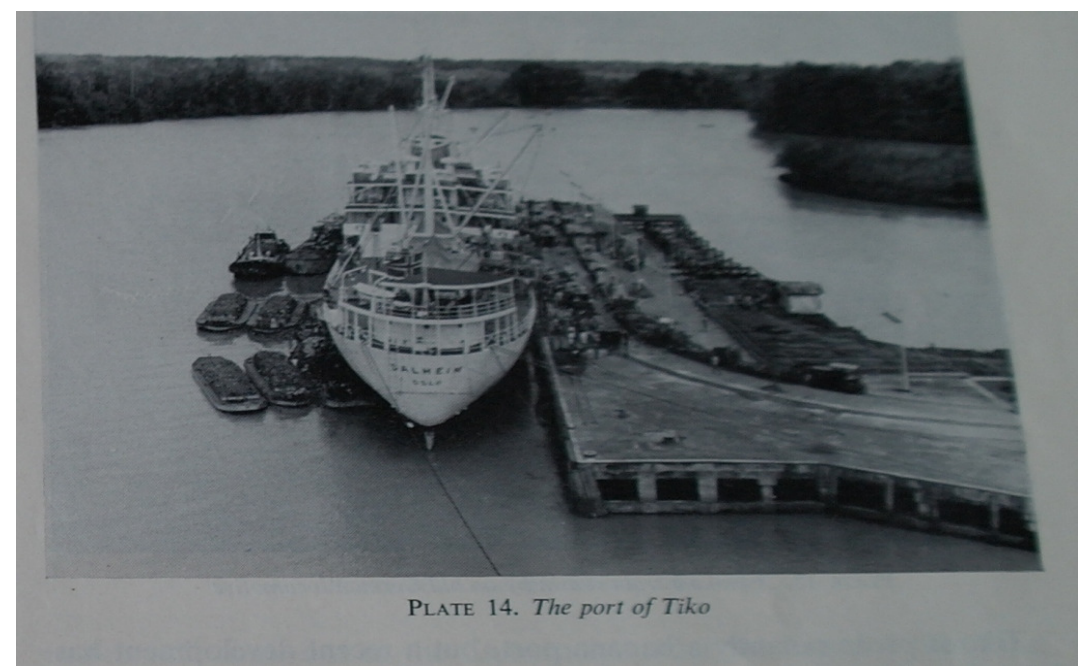

SOURCE:Victoria Southern Cameroons, 1858-1958 (Published for the Victoria Centenary Committee), 54

${ }^{8}$ Report on the Victoria Division, Cameroons Province written for the League of Nations by A.R. Whitmen, District Officer, September $30^{\text {th }}$, 1921(NAB)

${ }^{9}$ Ibid 
Nkwi: Rivers and Ports in transport history...

Table IV: Victoria and Tiko Port and importation of goods

\begin{tabular}{|l|l|l|l|}
\hline Spirits & Victoria Port & Tiko Port & Total \\
\hline Ale, beer etc & 13,841 & 7,693 & 14,534 \\
\hline Brandy & 221 & 79 & 300 \\
\hline Gin & 1,306 & 189 & 1,395 \\
\hline Rum & 4 & 20 & 24 \\
\hline Whisky & 735 & 88 & 823 \\
\hline Wines and gallons & 2,120 & 771 & 2,891 \\
\hline Liquors & 43 & 29 & 72 \\
\hline
\end{tabular}

SOURCE: File Ba (1930)5, Notes for the League of Nations report, $1930(\mathrm{NAB})$

The above table shows some contrasting relations between Tiko and Victoria in 1930. For instance out of a total of 14,534 tons of ale and beer that entered into the two ports, Victoria port registered 13,841 while Tiko registered 7, 693 making it almost half of what was registered at the Tiko port. Out of 300 tons of brandy, Tiko registered 79 while Victoria registered 221 making a difference of 142 tons. Gin registered a total tonnage of 1,395. Out of this Victoria registered 1,306 while Tiko registered 189 making a difference of 1,117 . The exception was only in rum where Tiko registered 20 tons while Victoria registered only 4 in a total of 24 .

\section{The Voices of the Victorian and Tiko returned migrants}

Victoria and Tiko as port cities had the trappings of modernity and thus attracted many people for various reasons. For instance, between 1924 and 1953 Victoria population had more than quadrupled from 1,577 inhabitants to 7,000. George Courade estimates that the number of Europeans in Victoria jumped from about 100 in the 1950 s to 250 at independence in 1961. Many of them ran department stores and shopping centers like John Holt, R\&W King, CCC, ICC and Pritania while the Lebanese tycoon, "Potokri" ran the monopoly in the film industry with two cinema theaters, "Rio"in New Town and "Rivoli" in Gardens.

Besides many people from the hinterlands, Nigerians and other people from West Africa migrated to Victoria for several reasons. Some came for just simple adventures to see and feel modernity. Some came as labourers in the plantations and ship yards 
while others were on transit to other parts of West Africa. What was crucial about their lives in Victoria is that they returned to narrate tales about Victoria even when the city had gradually petered out.

I left Kom with my friends, Ndifoyn Awoh and Ngang Chea. Malawa Fuka, Megne, Milibia, Yola Ntu and many others. It took us two days to reach Kubou's compound in OldTown, Bamenda. From Bamenda it took fifteen days to reach Bitoria (sic). We slept at Woyang in Bali; at Bamakwa Sabi and crossed Tang Sabi and spent the night at Fontem junction. From there we stayed at Nguti; Konye. and Kumba. From Kumba we stayed at Mbanga Bakundu; Muyuka; Ekona Benge. From Ekona Benge we passed through Molyko and stayed at Bolifamba. Very early we took off from Bolifamba to Bitoria (Victoria) where I saw the steamer carrying bananas and a plain of water. Victoria was the place which I saw wonders. The steamer was having constant smoke coming out from its head and only steaming. The day it was to go, it made a very large sound which you could hear very far from where it was. The whole sky was dark with smoke. From below the sound was different ahaang ahaang ahaang ahaang. This meant that its roots that were deep down were already coming up ready to move. When it was to take off finally, I heard a bass sound hиииииииииииия; hииииииииииииття; hииииииииииииииииип. At that moment the smoke became thicker and the sky darker while the sea was divided into two parts. It now took off for another world. In fact I wonder aloud and asked myself who on earth could have made such a big thing which could carry all the people from Kom. It was a big surprise to me and looked too big for me. I asked how people get into it. My friends who were already in Bitoria before me, showed how people entered it.

Our informant provides us with a clue as to how many people actually left Kom at any one time for the Victoria. From his 
story as many as 35 people at a time travelled down to the Coast with divergent ambitions. Some were traders while some were job seekers.Indeed, salt wata stories become more revealing metaphors. The stories as we have gathered from Peter bring to light the sensations and fascinations of an encounter. Moving salt water brought not only fish but very big sea water vessels with new cargo which workers spent most of the day unloading. Most of those who did the work were from the Bamenda Grassfields where no sea was to be seen. The waves showed that sea water also journeyed. In the morning the waves were usually low and in the evenings during high tides the waves came back depositing fish. The fish represent a metaphor -- just as the people had migrated to the Coast and would take home $k$ faang which represents the 'fish'.

After toiling for months and years the people came home with very changed habits. Their language, dress and mode of speaking reflected modernity, just as today many Grasslanders from the United States, Europe, Japan and China talk like European and Asian people. They wear long leather boots and cow boy hats, ear rings and even talk to their parents through interpreters; showing off that they have reached the depths of newness. They also come home with stories about the fascinations and sensations of Europe, America and Asia. These stories include obtaining money from machines and slotting in coins for coffee or food, and many fanciful things like luxurious Porsche cars that are available and cheaper to buy there. Both the people who had been to the Coast and to Europe and beyond constitute hierarchies in that they are more 'endowed with modern opportunities and opportunism than the others' (Nyamnjoh, 2005: 267). We cannot lose sight of the fact that these people, whether in the distant past or recently, re-constituted identities of their own.

Tiko had peculiar characteristics apart from the port and its plantations. It was more commercial in outlook than Victoria because of the overwhelming Ibo migrants. People migrated from hinterlands to look for employment and some came back to their areas of origin with stories and what they have learnt in Tiko. Cosmas Nchojie of Kom was one person whose going to Tiko was to have a lasting effect on Kom in terms of the modernity he got from there. He had migrated to Tiko not to work in the plantations but to learn photography. After studying it and gathered some money and 
bought a camera. He then became the first person in the Kom area to own a pin hole camera which was the talk of the day (Personal Communication, with Cosmas Nchoujie 13 August 2008). Back in the Kom area, the camera caused panic and frightened people as they were still to understand how somebody's image could be reproduced on a paper.

\section{The Ports and Consumption}

Hardly has the literature on African ports taken into account the consumption which it generated far and beyond the port. This section gives some anecdotal narratives which buttresses the fact that the ports of Victoria and Tiko in the 1940s and 1950s had its ramifications far beyond the port itself. For instance, those who ventured to Victoria and Tiko remembers thus in the artifacts they acquired especially radios, shoes and eye glasses. The tons of wines and cigarettes as well rums and whisky were not only reserve for the European populations. Africans jumped onto the band wagon of consuming modern things which came through the ports. For instance, the picture below shows some Victoria migrants displaying their modern attributes.

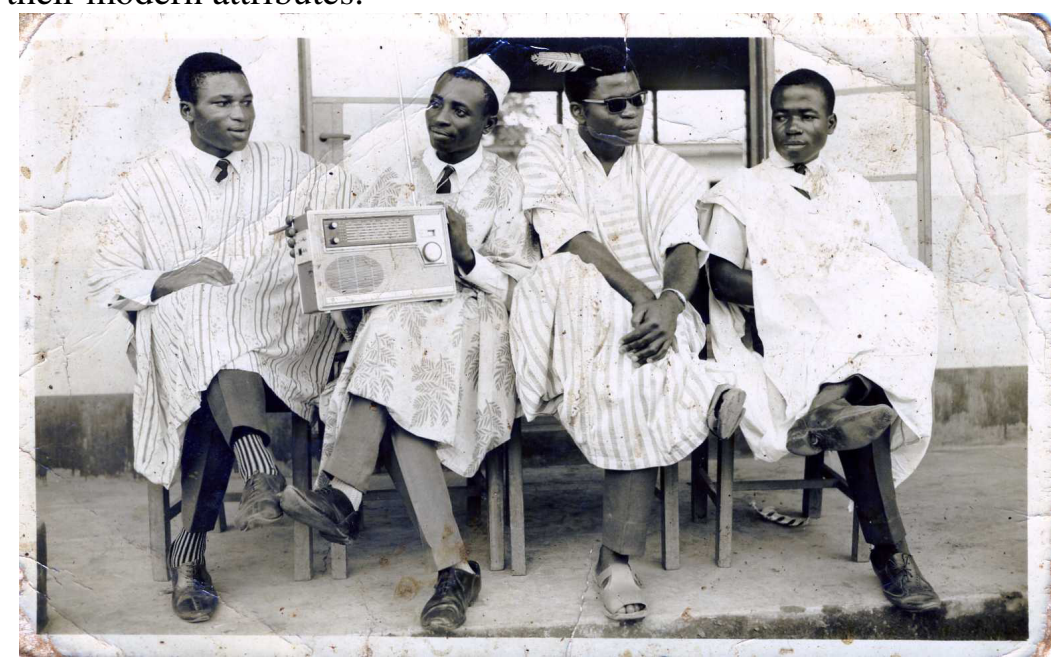

Francis is holding a radio probably a two band transistor. He worked with the Woodin company and the other friends with John Holt in Victoria. Their dressing styles, traditional regalia mixed with ties, 
eyeglasses and well ironed trousers symbolised a bricolage of a conventional binary-"tradition and "modernity". The way they crossed their legs shows how they found enduring modernity to embrace such 'modern' ways of sitting. Of relevance is the radio. In a world where television sets never existed, to possess a radio (was a status symbol which) made one a king in the eyes of the onlookers. Homes that had radios were centres of attraction for neighbours who came to listen (to the radio) although without understanding but for a few who had been to school. ${ }^{34}$.

In the photo below is an anonymous informant who literally adored a radio and told me that in those their days it was a pearl. He had saved money for five years to enable him to purchase the radio at UAC Victoria. Evidently its importance is depicted by the fact that the radio had its own pillow, a status symbol and a sign that he was obsessed with modernity.

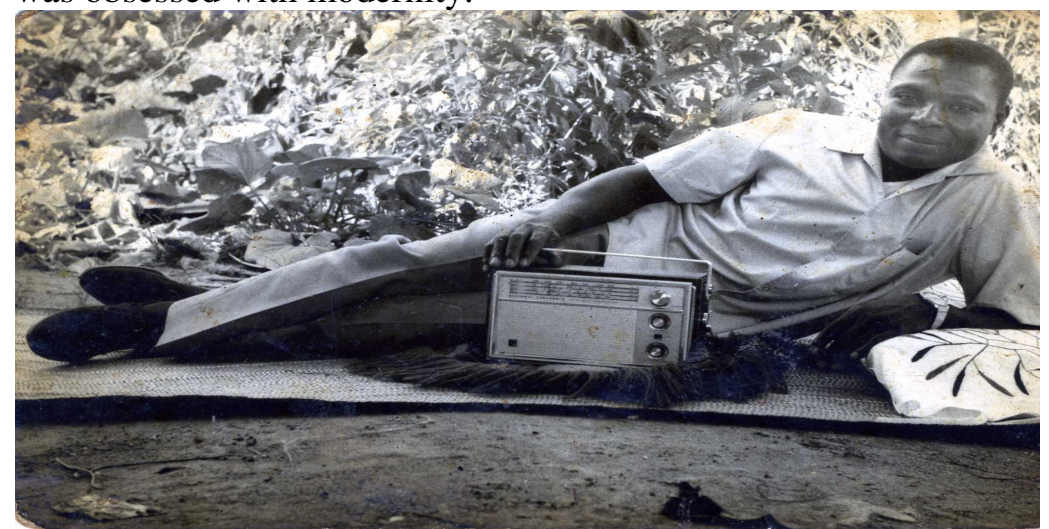

SOURCE: Anonymous informant with his radio which he bought in UAC shop in Victoria.

What is further intriguing in these returned migrants are concerned is the degree to which they constitute, agents of the modernity, a sort of middling Class. Weintein and Ricardo (2012) have recently published excellent essays in a volume which links the formation of the Middle Class to returning migrants sporting modern dress and habits. This is an important intervention, as we traditionally tend to think of the middling class as a predominantly very western phenomenon. Furthermore we also tend to regard mobile capital, not mobile labour, as an agent of modernization, 
Contemporary debates about the Multinational Companies and their apologists suggests or argue that the MNC is a blessing for people abroad because it finally brings modernity into their sleepy little villages. What this article shows is that migrant labour is just as much a factor in the modernization process. More importantly, it shows that "modernity" does not simply invade a village like an unstoppable juggernaut but sneaks in slowly and fits and bursts, carried by myriad actors. Historians and policymakers alike, who are still clinging to the last vestiges of the Modernization Theory, tend to treat mobile capital as the most important agent of modernization, but in Africa, taking the Cameroon western Grassfields as a case study, it was the Africans themselves, more often than not, who brought the trappings of modernity into their villages. In the process, these returnees initiated a fundamental revolution within the hierarchical organizations of their societies. The way returned migrants held the objects which they bought in Victoria close to their "chests" or revered them could as well make one to conclude that these were new forms of fetishes.

\section{Victoria and Tiko port cities became a crossroads of cultures}

Cultural, social or institutional features usually develop in port cities. The migration of people into Victoria and Tiko over the years both European and Africans alike led one to code name these areas as a crossroad of cultures, on one hand, there was the introduction of Christianity through churches and schools. As far as education was concerned as early as 1886 the German Governor Julius von Soden in pursuit of German education policy opened the first school in Victoria in 1887 and the pupils were mentored by Joseph Wilson. According to the 1913 statistics the Victoria school had a pupil population of 257 pupils making it the second largest school in the entire German colony. In 1957, the Victoria Divisional council was a proprietor of six senior primary schools and nine junior primary schools catering for some 1,105 boys and 480 girls. The number of Africans who initially occupied the Victoria settlement from Fernado Po gradually increased as many other groups of people migrated to Victoria. There were Nigerians, French Cameroonians, Togolese, Sierra Leoneans and many other indigenous peoples from the hinterland. These people migrated to enjoy the modernity of the 
Nkwi: Rivers and Ports in transport history...

city. The offshoots of these various peoples were the formation of tribal or improvement unions.

Improvement unions as the name came to be known in the post Second World War period had several objectives. Amongst these objectives was the desire of the migrant people to cities who wish to identify with kith and kin and secondly to send money back home to improve the lot of their people. Gradually these improvement unions although it took apolitical stand soon became political pressure groups. The Bakweri Improvement Union, Kom Improvement Union and Nigerian Fishermen Union all sprout up to identify themselves in Victoria with different and various motives. Thus identity and ethnicity was fast becoming a characteristic feature of the port city of Victoria.

Prostitution occupied a major place in Victoria and Tiko port cities. Women who wanted to enjoy the niceties of the city migrated to Victoria after casting off the yoke of patriarchal and even colonial controls and found themselves in Victoria. Prostitution the World over is one of the oldest professions and has attracted quite interesting studies in recent times (Coquery-Vidrovitch, 1997; Lukman, et.al 2011; Biarritz, 2000; Barrera, 1996; Spaulding and Bewick, 1995; Aderinto, 2010). The subject has been handled by sociologists, anthropologists and to a lesser extend historians. As a matter of fact, it should be given a deeper historical touch so that its continuities and differences in various contexts may be better understood. The complexities which went with the movement of those who became known as prostitutes in colonial Africa could best be understood within the brackets of globalisation and modernity. Warmington et.al (1967) maintains that in 1957 there were many prostitutes in Victoria who were mostly found in the congested immigrant settlements. They went on to assert that Victoria and to a was the most notable centres of prostitution, where the sex ratio in the resident population was 203 males per 100 females, excluding the large population in the plantation that visit these settlement.

\section{Rivers in Cameroon History}

Rivers in Cameroon has played commercial, social and cultural roles. The commeracial role played by rivers in Cameroon was aptly captured by Ralph Austen and Jonathan Derrick in their Middlemen of the Cameroons Rivers: The Duala and their Hinterland, c.1600- 
1960 The focus of this book is on the Duala men who had entered the International scenario as merchant brokers in the pre-colonial trade in which they trade in ivory, slaves and palm products but whom under the colonial rule used the advantages which they had gained from earlier rivera in trade to develop cocoa plantations. The authors maintain that the Dualas enjoyed an exclusive access to an extensive network of rivers connecting the coast and the interior. They occupied the focal point of a trading network that extended from Wouri estuary up the various river systems of the Cameroon littoral and their most lucrative activity was bartering goods obtained through canoe expeditions inland in the $19^{\text {th }}$ Century mainly palm oil and kernels plus ivory for imported commodities brought to Douala by European traders. (Austen and Derrick, 1999). This has lucidly shown the economic importance of rivers to the Dualas during the pre-colonial and colonial periods.

Further south, rivers played the role of "communication wires". The Nyong in the south seems to have offered the greatest advantages, for it was very navigable. Water transport therefore became quite crucial to the colonial administration as their mails and goods were first transported via that medium.As we have argued elsewhere (Nkwi \& de Bruijn, 2014:220), all inland mail and other goods came by boat and were then transported further inland. The main stations for this boat transport were Tiko, Victoria, Ikom and Bonaberi. Water tides determined when the launches anchored and set sail. The role played by river transport and the role of interimperial British- French cooperation in transport were further echoed by the Resident of the Cameroons Province, P.V.Young, in the following words:

An alternative which I might suggest and which might take some reconsideration is that all transport by water shall be done via Victoria, Tiko and then to Bonaberi, thence by the French Railway to Nkongsamba by this route an enormous saving of carrier transport is affected...The connections would be as follows: from Calabar there is a monthly boat running to Victoria and very often Tiko, there is the ordinary Mail Steamer Service to Victoria about once in five weeks, from Tiko to Bonaberi there is the French weekly service between 
Bonaberi and Tiko which leaves every Wednesday ....In my own opinion this is the only satisfactory way for mail and packages to be dispatch. ${ }^{10}$.

In 1906 Otto Schkolziger photographed the launch on the waters of Bonaberi with mail and packages. Below is the photograph.

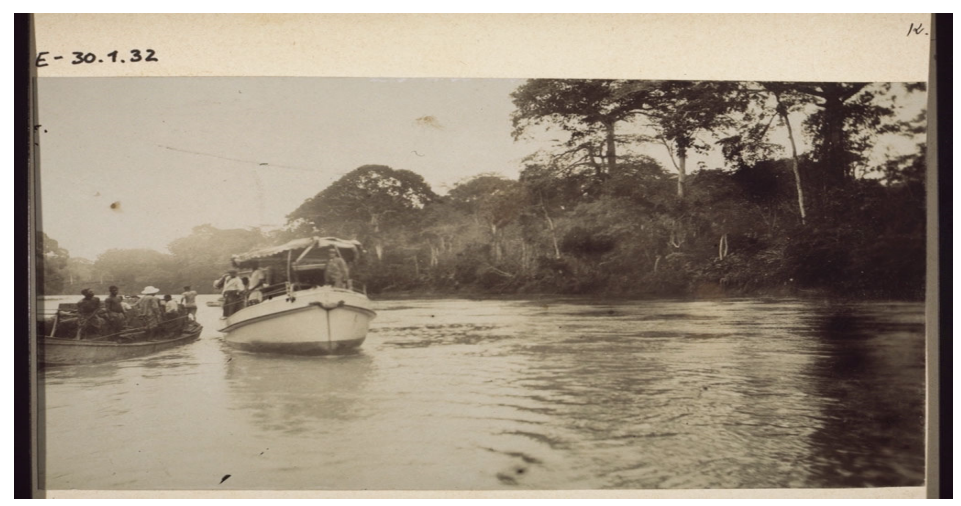

In the North of Cameroon River Benue was very important in several ways, first in agriculture and secondly as a transport route. Rising from the Adamawa Plateau the Benue first first flows north, then runs in a generally westerly direction until its junction with the Niger Lokoja. At high water, during the months of August and September, the river Benue becomes wide navigable waterways about a mile in width from bank to bank. The flood plains of the Benue and its tributaries received much debris which made the plains of the Benue and its tributaries one of the best farming and grazing lands (Njeuma, 1978). The River Benue provided a large route from Garoua to the Niger River. It was not until the opening of a railway line to Ngaoundere in 1974, traffic on the Benue-Niger route was the lowest cost means of transport available in North Cameroon to the Europeans and indigenous population alike. Long before the completion of the cement factory at Figuil in late 1960s, the Benue-Niger route had been economic chiefly for the import of fuel and cement and then exported cotton (Nelson, et. al., 1974:

${ }^{10}$ File Bb (1917)1 Flag Post System (NAB) 
278).Rudin (1938: 104), notes that "whites coming into the interior of the Cameroon were interested in the streams that might make travel easier and the transportation of goods less expensive". Furthermore, along the Longone and Shari rivers which flew from the south into Lake Chad there was rich farming activities (Rudin, 1938:105).

Socio-culturally some rivers have gotten additional importance because some ethnic groups attached relative importance to their migratory history. Although there is much controversy the Bassa migrated to their present side between Dibamba, Sanga and Nyong rivers and had moved north along the Wouri and Banen rivers long before the Bakoko and Fang ethnic groups (Johnson, 1970:60). According to Ewumbue-Monono (2015:3) "Most of the villages in the Buea municipality were founded around river sources". These rivers and springs influenced the cultural history of the people. One of the rivers whose importance in economic and socio-cultural aspects in Cameroon history has been River Mungo to which our attention now turns.

\section{Locating River Mungo}

As I argued it elsewhere, (Nkwi, 2013:95-113), River Mungo has a catchment area of 4,200 square kilometers (app.1, 600 miles). It is 150 kilometers (93 miles) long. It takes its rise from the Rumpi Hills to the North and is fed by tributaries from Mount Kupe and Bakossi mountains. (Neba, 1984). The river is navigable throughout the year for a distance of about 100 kilometers. It empties its waters into the mangrove swamps and the Atlantic Ocean alongside with other Cameroon rivers like Wouri and Dibamba

The flora and fauna of the surroundings of the river was captured by Esser, Chilver and Roschenthaler (2001:45) in the following words:

The banks of the Mungo are magnificently covered with forests... and everything here teems with life. One can see eagles, herons, snakes and monkeys, as well as multicolored parrots on the trees while on the surface of the water there dance butter flies and dragon flies the size of sparrows. Now and then one hears the trumpeting of elephants, the cry of 
predators, and the melancholy and monotonous honking of the iguana

Point is well taken. Apart from the flora and fauna, the peoples on the banks of river Mungo carry out agriculture and fishing when there are low tides. The partition of Cameroon in 1916 instead of dividing the Mungo people rather witnessed people who frequently crossed the Mungo River for various purposes on both sides of the river. They crossed to attend tribal meetings and to celebrate important events. From time to time, as family obligations or trade required the Mungo of British Cameroons visited their principal town, Bonako on the French side of the boundary ${ }^{11}$. The long history of economic, socio-cultural interactions between the Duala and the Bakweri at the coast and the partitioned Mungo, Balong, Bakossi, and Mbo people inland meant that the boundary was frequently ignored along the River Mungo. Market women such as the "buyam sellams" who traded in goods between Southern Cameroons and French Cameroons on a regular basis were always bent on seeing that border restrictions were dismantled (Johnson, 1970: 337; Kah, 2003: 117). The porosity of the boundary implied directly and/or indirectly that these historical communities were always in need to be with their kith and kin across the Mungo River as they had done during the German administration.

In the middle years of the British administration it became apparent to the Resident in Buea that the interaction across the border could not be prevented. The Resident for the Cameroons Province cautioned against the grave consequences of attempting to prevent ethnic immigrants move into both French and British administrative areas (Kah, 2003). The constant movements by these communities into and out of British Southern Cameroons revealed that it was just a matter of time before the artificial boundary gave way to the free movement of culturally, linguistically and

\footnotetext{
${ }^{11}$ File Ba (5) 1916/2, Report of His Britannic Majesty's Government to the Council of the League of Nations on the Administration of the Cameroons under British Mandate for the Year 1924 (London: H.M.S.O., 1925)(NAB)
} 
historically related peoples, but importantly showed that crossing the river was almost a way of life $\mathrm{e}^{12}$.

Economically, The River Mungo was important for people who wished to conduct trade on the other side of the river. The photograph below shows people either returning from the market or still going to attend it. For them they needed such canoes to overcome the river. The picture below show traders and people returning from the market in the river

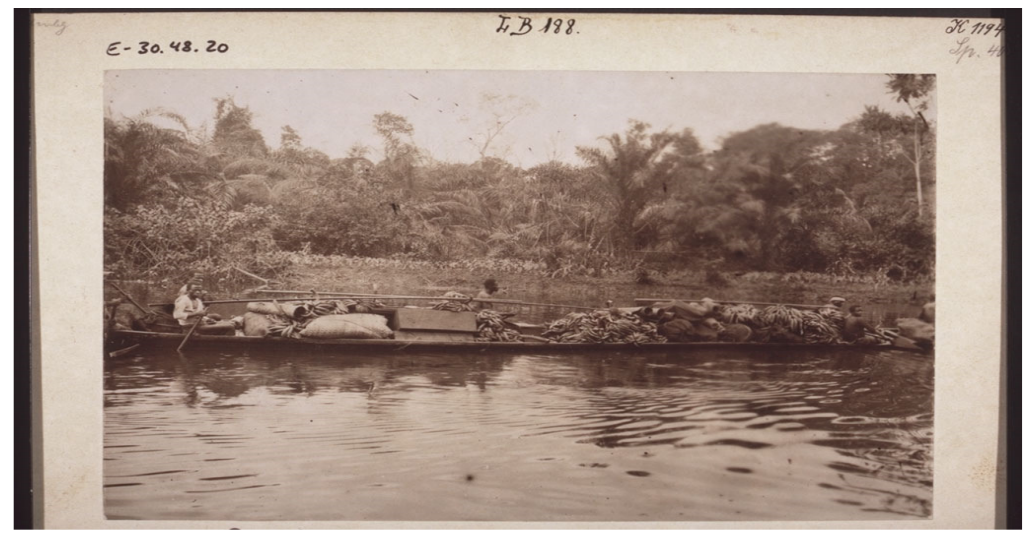

A cursory observation of the photograph shows that many assorted goods were inside the canoe. There are bags of salt and may be cocoa, cocoyams, soap, plantains and bananas. This suggests that the people were either going to the market or coming from it. In either direction it could be assumed that trade was quite possible because of the river.

\section{Rivers, Canoes and Canoe Boys}

One of the greatest technologies which Africans have developed to torpedo their rivers was canoes sometimes often known as dugout canoes. The Dufuna canoe from Nigeria is estimated to be one of the oldest whose age is estimated to be 8000 years old. It is the third-

\footnotetext{
${ }^{12}$ File $\mathrm{Tb} / 1925 / 1$, League of Nations Report for the Cameroons Province; File $\mathrm{Tb} / 1924 / 1$, League of Nations Report for the Cameroons Province;File.Aa/1918/37, Movement of people in the Cameroons Province (NAB)
} 
Nkwi: Rivers and Ports in transport history...

oldest worldwide. The well-watered tropical rainforest and woodland regions of sub-Saharan Africa seemed to have provided both the waterways and the trees for such types of canoes, which are commonplace from the Limpopo River basin in the south through Eastand Central Africa and across to West Africa. African Teak is the timber favoured for their construction, though this comprises a number of different species, and is in short supply in some areas. The African Teak (Pericopsis elata,) is a specie of legume in the Fabaceae family and is found in Cameroon, Republic of the Congo, Democratic Republic of the Congo, Ivory Coast, Ghana, and Nigeria. These canoes are peddled across deep lakes and rivers or punted through channels in swamps (see makoro) or in shallow areas, and are used for transport, fishing and hunting, including, in the past, the very dangerous hunting of hippopotamus In pre-colonial Africa, and especially in the empires of Western Sudan. July (1975: 185) notes that goods which arrived from Timbuctu were usually loaded into canoes with a capacity of twenty or thirty tons and taken three hundred miles upstream to Jenne.

The canoes are peddled by canoe boys. These boys were muscular to enable them performed the labour of taking the canoe both up and downstream. In the central African state of Zambia, Gewald (2009) informs us that the journeys upstream, depended on the muscle power of paddlers, took a minimum of at least ten days travelling time, before the first company administrative centre was reached and allowed for the new administrative officials to adapt to their new terrain, and perhaps more importantly allowed for the paddlers, and by extension their Community, to gain insight into the habits, quirks, attitudes, and characters of the new men being sent to administer. As with the porter age described above, the use of barges and canoes, illustrates once again the dependence of the colonial state being established on the muscle power, if not goodwill, of the local population.

In Cameroon both during the colonial and post colonial periods canoe boys were charged with the duties to paddled across the stream, indigenous people going to the market, farms or attending festivals. The colonial administrators also depended quite much on canoes for their goods to be transported or when they were going on tour. Thus Rivers Manyu, Sanaga, Mungo, Nyong, Benue and Ntem were quite crucial. Apart from just peddling people and 
goods across these rivers, there canoe mechanics or repairers. Dipoko Joseph was one of the canoe boys whom I contacted during the fieldwork. He was the grandson of Eyemi who had been a canoe boy on the River Mungo. Born in 1944 he claims that he has been doing this job throughout his life. According to him a canoe boy is supposed have a firm knowledge of water currents to enable him master the way to move with his canoe. He should be brave as well (Personal communication with the author, 23 July, 2014). This same version was repeated by other canoe boys whom I contacted on River Manyu on 30 March 2012. Their story suggests that in addition to their ingenuity and muscles, the water currents played a very vital role to facilitated their job and a knowledge of how the direction which these currents flew also illustrate the African technological know-how long developed before the advent of colonial rule.

Canoe "engineers" commanded even more attention. These were mechanics who were charge with the functions of repairing the canoes when they went bad. Using all types of chronic tools, these are people who are blessed with the intelligence to stitch the boats as if it was cloth. They used different tools to repair canoes depending on the nature of the 'wound'. Along the banks of the navigable rivers, canoe repairing shops are found. For instance, Eyong works as a canoe repairer along the banks of River Manyu. He uses the hammer and copper wire when need arises. According to him, he inherited the profession from his grandfather and now had opened a "school" only to train canoe mechanics. He further maintained he is like motor car mechanic who repairs cars depending on the problem the car it encountered. He said:

I have been repairing canoes since 1960 when John Holt was still using the Manyu River. The problems with canoes vary a lot. The wood which canoes are made are not iroko neither are they very hard wood. This type of wood quickly develops holes and water can easily filled the canoe. Sometimes when this happens in the middle of the river when there is no technician, canoe boys are charged with carrying out the water as it enters the canoe. When they finally bring it out here I am in charge of repairing the damage. Depending upon the problem, I can either use 
copper wire or nails or hammer to adjust the problem. In 1993, the work was so intense that I decided to open a workshop with 10 apprentices (Personal communication, 23 August 2013)

\section{Conclusion}

Rivers have been areas that have facilitated the mobility of goods and people while. Africa in particular with a few navigable rivers did play political, social and economic roles. European explorers were commanded to break thought the interior of Africa and understand the navigability of these rivers. Some of these rivers shaped diplomatic relations in Africa and Europe as well during the period of the scramble and after. In Cameroon the rivers and ports in colonial Cameroon became quite instrumental to the colonial administration. Through them the cost of transport was significantly reduced. It was through rivers that goods and colonial personnel were transported.

Despite the role although with its own limitation that the rivers and ports played the historiography of Cameroon during that period had glossed over the role. This paper has contributed to filling this gap. It has shown that out of the ports many related issues were in place. It has shown that ports were not only about economic transactions. The people who migrated to the areas acquired new cultures, consumed foreign and modern things while prostitution took roots. Rivers in themselves became sites which indigenous technologies facilitated the transportation of goods as well as people. Therefore rivers and ports saw the gradual birth of a middling class. On one hand those who migrated to the port cities and returned with modern goods and on the other hand those who commanded the tides of the rivers and the repaired the canoes became a social category apart from their peers.

*Walter Gam Nkwi, Department of History, University of Buea, SW Region, Cameroon. nkwi.walters@ubuea.cm 


\section{References}

Aderinto, S.A. (2010)"Sexualized Nationalism: Lagos and the Politics of Illicit Sexuality in Colonial Nigeria, 19181958".PhD Diss. University of Texas.

Aka, E. A.(2002The British Southern Cameroons, 1922-1961: A Study in Colonialism and Underdevelopment. Madison, Platteville.

Ardener, E. (1956) Coastal Bantu of the Cameroons. London:

Macmillan.

Ardener,S. (1968) Eye-Witnesses to the Annexationof Cameroon, 1883-1887.Buea, Cameroon: Government Printing Press

Austen, R. A. and Jonathan Derrick.(1999)Middlemen of the Cameroons Rivers: The Duala and their Hinterland, c.1600-1960. Cambridge: Cambridge University Press.

Baginski,H. (1944. "The Sixtieth Anniversary of Rogozinski's Expedition to the Cameroons". The Geographical Journal103 (1/2)): 72-75

Baker. G. L (1996) Trade Winds on the Niger: Saga of the Royal Niger Company, 1830-1971. London: Radcliffe Press.

Barrera, G.(1996) "Dangerous Liasons: Colonial Concubinage in Eritrea, 1890-1941" Programme of African Studies, Northwestern University, Evanston.

Barritz, T.A. (2000) Commercial Sexual Exploitation of Children: Youth involved in prostitution pornography and Sex Trafficking. Washington: Youth Advocate Programme International.

Coquery-Vidrovitch, C. (1997) African Women: ModernHistoryBoulder, Colorado: Westview Press.

Ebune, J B. (1992) The Growth of Political Parties in Southern Cameroons, 1916-1960.Limbe: Presbook.

Ewumbue-Monono, Churchill (2015). Buea, Capital of the Cameroons: Symbol of the Nation and of Reunification. Buea: CEREDDA Publication

Crowder,.M. (1968) West Africa Under Colonial Rule. London: Hutchinson University Press

Elango Lovett Z. (1987) The Anglo-French Condominium in Cameroon, 1914-1916: History of Misunderstanding. Limbe, Cameroon: Navi-Group Publications. 
Nkwi: Rivers and Ports in transport history...

Epale, S. J. (1985).Plantations and Development in

WesternCameroon, 1885-1975: A Study in Agrarian

Capitalism. Los Angeles: Vantage Press.

Esser, M., Chilver; E. M. Ute Röschenthaler, (2001) .Cameroons

tycoon: Max Esser's expedition and its consequences.

London: Berghahn Books.

Fage, J.;Roberts Donnelly; Roland Anthony Oliver, (1986). The Cambridge history of Africa. Cambridge: Cambridge University Press.

Fanso, V. G. (1989) Cameroon History for Secondary Schools and Colleges, Vol. 1: From Prehistoric Times to the Nineteenth Century. Hong Kong: Macmillan Education Ltd.

Fanso,V.G. (1989) Cameroon History for Secondary Schools and Colleges, Vol.II: From Pre-historic Times to the Nineteenth Century. London: Macmillan.

Gardinier, D. (1963) Cameroon: United Nations Challenge to French Policy. London: Oxford University Press.

Geschiere, P. (2001) "Issues of Citizenship and Belonging in present day Africa" In L. Kropacek and P. Skalnik (eds) Africa 2000: Forty Years of African Studies in Prague. Set Out: Prague

Gewald, J-B (2009) "People, mines and Cars: Towards a revision of Zambian history, 1890-1930" In Jan-Bart Gewald, Sabine Luning and Klaas van Walraven (eds) The Speed of Change: Motor Vehicles and People in Africa, 1890-2000. Leiden: Brill

Geyer, M, (2010) “Portals of globalisation" In Eberhard Winfred and Lubke Christian (eds) The Plurality of Europe: Identities and Spaces (Leipzig: Leipziger Universitatsverlag.

Hamdy A. H, and Ahmad Al Rasheedy (2007) "The Nile River and Egyptian Foreign Policy Interests" African Sociological Review, Vol. 11, No. 1: 25-27.

Hartman, W., Jeremy Silvester \& Patricia Hayes (eds.) (2004)The Colonising Camera: Photographs in the Making of Namibian History. Cape Town, Windhoek and Athens $\mathrm{OH}$ : UCT. Press.

Hopkins, A.G. (1973) An Economic History of West Africa.

London: Longman 
Johnson,W. (1970) The Cameroon Federation: Political Integration in a Fragmentary Society Princeton: Princeton University Press.

Kah, H. K. (2003), “The Reunification Movement in Cameroon, 1948-1961:Socio-Cultural and Economic Considerations" Journal of Applied Social Science. Vol.4, No.2:117-135

Kah, H. K. (2013), "Palm Produce Trade in Cameroon's Cross River Region from early 1800s to 1961" Ghana Social Science Journal, Volume 10, Numbers 1 and 2: 107-128

Kale,P. M. (1967)Political Evolution in the Cameroons. Buea, Cameroon: Government Printing Press.

Koning, P. and Francis B. Nyamnjoh (2003). Negotiating an Anglophone Identity: A Study of the Politics of Recognition and Representation in Cameroon. Leiden\& Boston: Brill, Afrika-Studiecentrum Series, No 1

Kratz, C. A.(1994) "On Telling/Selling a Book by its Cover", Journal of Cultural Anthropology, Vol.9, No.2 179-200

Middell,M.and Katia N. (2010) "Global History and the Spatial Turn: From the impact of area studies to the Study of Critical junctions of Globalisation" Journal of Global History Vol.5, Issue 1: 149-170.

Miller, F. P.; Agnes F. Vandome; John Mc Brewster (eds) (2011) Mungo River, Cameroon. USA: Alphascript publishing.

Milne,M. (1999)No Telephone to Heaven: From Apex to NadirColonial Service in Nigeria,Aden,the Cameroons and the Gold Coast, 1938-1961.England:Meon Hill Press.

Neba, A. (1999) Modern Geography of the Republic of Cameroon. Bamenda, Cameroon: Neba publishers.

Nelson, H.D.; Margarita Dobert; Gordon C. McDonald; James McLaughlin; Barbara Marvin; Philip W.Moeller (1974) Area Handbook for the United Republlic of Cameroon. Washington: US Government Printing Office.

Ngoh, V.J. (1988)Cameroon 1884- 1984: A Hundred Years of History.Yaounde,Cameroon: CEPER.

Ngoh,V.J(2004.)..SouthernCameroon's 1922-1961: A Constitutional History. Ashgate: Burlingto. Njeuma, M.Z. (1978) Fulani Hegemony in Yola (Old Adamawa, 1809-1902. Yaounde, Cameroon: CEPER. 
Nkwi: Rivers and Ports in transport history...

Nkwi, W. G. ( 2004)“The Anglophone Problem" InVictor Julius Ngoh (ed)Cameroon FromFederal to Unitary State,19611972:A Critical Study.pp.185-209.Limbe, Cameroon: DESIGN House.

Nkwi, W.G. (2013) "The Mungo: A River of many Cultures in Cameroon History, c,1884-1969"pp. 95-113. In Pierre Fandio (eds) Popular Culture and Representation in Cameroon, Kansas City, MO: Miraclaire.

Nkwi, W.G.and Mirjam de Bruijn (2014) "Human Telephone Lines": Flag Post Mail Relay Runners in British Southern Cameroon (1916-1955) and the Establishment of a Modern Communications Network" International Review of Social History, Special Issue 22: 211-235.

Oliver, R. (1958). Sir Harry Johnston and the Scramble for Africa. New York: St. Martin's Press

Perry, M.; Chase, Myrna; James R. Jacob and Theodore H. Von Laue (1989).. Western Civilisation: Ideas Politics and Society. Boston: Houghton Mifflin Company.

Pinney, C. (2004), Photos Of The Gods: The Printed Image And Political Struggle InIndia London: Peaktion Books.

Rubin,N.(1971)Cameroon: An African Federation. London: Pall Mall.

Rudin,H. (1938). Germans in the Cameroon, 1884-1914: A Case Study in Modern Imperialism. New Haven: Yale University Press.

Spaulding, J.\& Stephanie B. (1995) "Sex Bondage and the Market: The Emergence of Prostitution in Northern Sudan" Journal ofthe History of Sexuality, Vol.5: 512-534

Underhill, Edward Bean (1958)Alfred Saker: Missionary to Africa: ABiography London: The Carey Kingsgate Press.

Urry, J. (1995) Sociology beyond Societies (London: Routledge, 2000); Also see his other book, Consuming Places. London: Routledge.

Webster, J.B; Boahen, A.A. (1980) The Growth of African Civilisation: The Revolutionary Years West Africa since 1800. London: Longman.

Weinstein, B. \& Abel Ricardo L. (2012)The Making of the Middle Class: Towards a Transnational History of Middle Class. Duke: University of Duke Press.

Welch,C. (1960) Dream of Unity: Pan Africanism and Political Unification in West Africa. New York: Cornell University Press. 